\title{
TERCÜME MAKALE/TRANSLATION
}

\section{MALEZYA'DAKI MÜSLÜMANLARIN “SOSYAL HIZMET” FAALIYETLERI}

Saad, Z. M., Hatta, Z. "Muslim Social Work Activities in Malaysia". Islamıc Socıal Work Practıce: Experiences Of Muslim Activities in Asia. ed. Kana Matsuo. (4: 61-85). Shukutoku University, Asian Center for Social Work Research (ACSWR), 2016.

https://bit.ly/3oymnge

$$
\begin{array}{r}
\text { Fahriye Sena EROĞLU } \\
\begin{array}{r}
\text { Yüksek Lisans Öğr., Sağlık Bilimleri Ünv. Hizmet Ana Bilim Dal,, İstanbul } \\
\text { Graduate Student, Health Sciences University, Department of Social Work } \\
\text { fahriyesenaeroglu@gmail.com } \\
\text { orcid.org/0000-0002-2334-0070 }
\end{array} \\
\text { Undergraduate Student, Hacettepe University Department of Translation and Interpreting } \\
\text { Saliha Yaman POLAT } \\
\text { syaman96@gmail.com }
\end{array}
$$

Öz

$\mathrm{Bu}$ çalışma Malezya'daki İslami sosyal hizmet faaliyetlerini incelemek amacıyla ele alınmıştır. Malezya'daki profesyonel sosyal hizmet faaliyetleri hakkında bilgiler verilmiş ardından İslami öğretilerin ve sosyal hizmetin ortak değerleri üzerinde durulmuştur. Çalışmanın amacı câmilerin, kurumların ve üstadların/imamların sosyal hizmet alanında neler yaptıklarını kayıt altına almaktır. Araştırmanın diğer amacı ise Müslümanların İslami sosyal hizmet faaliyetlerine katılma nedenlerini incelemektir. Bu kapsamda araştırmacılar karma yöntem kullanmışlardır. Persekutuan Cami imamı, Kubang Pasu ilçesinden bir zekât memuru ve Nusret Vakfı başkanı ile yarı yapılandırılmış görüşmeler yapılmış ve bu kurumların sosyal hizmet faaliyetleri incelenmiştir. Bununla beraber sosyal hizmet faaliyetlerine katılma nedenlerini araştırmak için 20 imam ile anket uygulaması gerçekleştirilmiştir. Üstad/imamların genel olarak sorumluluk duygusu ve toplumun ihtiyaçlarını karşılamak amacıyla sosyal hizmet faaliyetlerine yöneldikleri ifade edilmiştir. İmam/üstadların yardımcı rolleri mikro sosyal hizmet çerçevesinde, Zekat Toplama Merkezi ve Nusrah Vakfı'nın çalışmaları makro sosyal hizmet çerçevesinde değerlendirilmiştir. Sonuç olarak İslami öğretilerin ve sosyal hizmet uygulamalarının benzer değerleri paylaştı̆̆ı vurgulanmıştır. [Mütercim]

Anahtar Kelimeler: Malezya, sosyal hizmet, İslami sosyal hizmet

\section{MUSLIM SOCIAL WORK ACTIVITIES IN MALAYSIA}

Abstract 
This study is undertaken to examine Islamic social work activities in Malaysia. Information was given about professional social work activities in Malaysia, and then the common values of Islamic teachings and social work were emphasized. The aim of the study is to record what mosques, institutions and masters / imams do in the field of social work. Another aim of the study is to examine the reasons why Muslims participate in Islamic social work activities. In this context, researchers used mixed method. Semi-structured interviews were held with the Persekutuan Mosque imam, a zakat officer from Kubang Pasu district and the head of the Nusret Foundation, and the social work activities of these institutions were examined. In addition, a questionnaire was conducted with 20 imams to investigate the reasons for participating in social work activities. It is stated that the masters / imams generally tend to social service activities in order to meet the needs of the society and sense of responsibility. The auxiliary roles of the imams / masters were evaluated within the framework of micro social service, and the activities of the Zakat Collection Center and Nusrah Foundation were evaluated within the framework of macro social service. As a result, it was emphasized that Islamic teachings and social work practices share similar values. [Translator]

Keywords: Malaysia, social work, Islamic social work

Atıf / Cite as: Saad, Z. M., Hatta, Z.. "Malezya'daki Müslümanların "Sosyal Hizmet" Faaliyetleri”. çev. Fahriye Sena Eroğlu-Saliha Yaman Polat. Apjir 5/1 (Nisan 2021), 141-161.

\section{Malezya'ya Kısa Bir Bakış}

Malezya, 1 Ocak 2015 tarihi itibarıyla yaklaşık 30,6 milyon nüfusu ve 329,847 kilometre karelik toplam yüzölçümü ile doğal kaynaklar bakımından zengin olan bir ülkedir. Malezya, 330,434 kilometre kare (Japonya'nınki 377,900 kilometre kare) büyüklüğündeki çok etnik yapılı ve çok dinli bir ülkedir. Nüfus esas olarak üç etnik gruptan: Malay ve yerliler (\%66.1), Çinliler (\%25.2) ve Hintliler (\%7.5)'den oluşmaktadır. Malaylar Müslüman olup Çinliler ağırıklı olarak Budist veya Konfüçyüsçüdür, Hintlilerin çoğunluğu ise Hindu, küçük bir azınlığı Müslüman ve Hristiyandır. Her etnik grup, yaşamlarında baskın bir rol oynayan kendi dinlerine ve kültürel inançlarına sadıktır.

Malezya, nüfus yaşı bakımından, yaşlanan bir toplumun aksine nispeten gençlerin yaşadığı bir ülkedir. 2014 yılında doğum sayısı ölüm sayısından fazla oldu ve dolayısıyla nüfus, yaklaşık \%1,58 arttı (Country Meters, 2015). Ülke, 1970'lerden bu yana, ekonominin 19851995 döneminde ortalama \%7,3 oranında büyümesiyle sürekli bir ekonomik gelişme kaydetmiştir. Ancak düşük doğal gaz ve emtia fiyatlarına ilişkin mevcut küresel ekonomik belirsizlikler nedeniyle 2016 yılı için büyüme oranının \%4,5 civarında olması beklenmektedir.

2014 yılında kişi başına gayri safi yurtiçi hasılası (GSYiH) 7,04,14 ABD doları olan Malezya, orta gelirli bir ülkedir. 1960 ile 2014 yılları arasında kişi başına düşen ortalama GSYiH 3.357,16 ABD doları olup, maksimum değere 2014 yılında 7304,14 ABD doları ile ulaşılırken, en düşük değere 1960 yılında 986,48 ABD doları ile ulaşılmıştır (Trading Economics, 2015). Dolayısıyla, 1970'ten 2014'e kadar Malezya'da sırasıyla \%52,4 ve $\% 0,6^{\prime}$ lık rakamlarla yoksulluk konusunda önemli bir azalma olmuştur (Chi, 2015). 44 yılda yoksulluk oranı \%51 azaldı. Bu, refahta acil iyileştirmelerin yanı sıra gelir kazanma fırsatlarını geliştirerek sürdürülebilirliği sağlamayı amaçlayan kapsayıcı yoksulluğu ortadan 
kaldırma önlemleriyle başarıldı. Buna rağmen kırsal yoksulluk, kentsel alanlara göre üç kat fazladır; en büyük farklar doğu kıyısı eyaletleri ve Doğu Malezya'dadır (Ng ve Ratnam, 2012).

Mayıs 2015'te 13.763 .000 olan istihdam edilen kişi sayısına nazaran Haziran 2015'te 13.838.000 kişi istihdam edildi. İstihdamdaki bu artış, Malezya hükümetinin mal ve hizmet vergisi (MHV) uygulamasından kaynaklandı. MHV'nin uygulanması, genel giderler ve harcamaları artırdı, bu da daha fazla ev hanımının kendi harcamalarını karşılamak için çalışmaya karar vermelerine neden oldu. Ayrıca Malezya Kraliyet Gümrük Departmanı, tüm MHV sistemini desteklemek için daha fazla eleman işe alarak MHV'nin uygulanması aracılığıyla insanlara daha fazla iş fırsatı sunarken, özel sektör de aylık denetimler ve gümrük departmanına hesap beyanları gerektiren MHV sistemini idare etmek için daha fazla personel istihdam etti. 1985 ve 2015 yılları arasında ortalama istihdam edilen kişi sayısı 11.565.770 olup, en yüksek sayı Haziran 2015'te 13.838 .000 'e, en düşük sayı ise Aralık 1985'te 5.624.600'e ulaşmıştır. Şu anda işsizlik oranı \%3,2 civarında seyretmektedir. Mart 1999'da en yüksek işsizlik oranı \%4,5 ile kaydedildi, Asya ekonomik krizinin etkisi küçük işletmelerin kapanması ve kamu sektöründeki işe alımların dondurulmasında görüldü. Buna karşılık \%2,7 ile en düşük istihdam oranı 2012'de olmuştur (Trading Economics, 2015b).

2010 yılında uygulanan ve 2020 yılına kadar Malezyalılar için yüksek bir gelir statüsü elde etmeyi amaçlayan Yeni Ekonomik Model (YEP), ülkenin birden fazla ekonomik başarı elde etmesine önemli ölçüde hizmet etti. Ülkedeki özel sektör günümüzde artık büyük ölçüde gelişmiş durumundadır. Büyüme öncelikle sanayilerde ve kamu hizmetlerinde gerçekleşirken, insanların yaşam kalitesinde de önemli değişiklikler gözlemlendi.

Malezya'nın kamu sağlık hizmetleri, hükümet tarafından yüksek oranda sübvanse edilip güçlü bir sağlık hizmeti altyapısı sağlamaktadır ve böylece vatandaşların \%95'i için erişilebilir durumdadır. Sağlık Bakanlığı (SB) memurlara, emeklilere ve muhtaçlara ücretsiz sağlık hizmeti vermektedir. Sağlık hizmeti yapısı, 1957'deki ülkenin bağımsızlığı ile yirmi yıllık hızlı bir değişim yaşadı. Malezya'daki sağlık hizmetleri, bu sabit reformlarla evrensel kapsama ulaşıyor olarak görülebilir.

Malezya eğitim sistemi, 1824 civarında başlayan sömürgecilik nedeniyle İngiliz sisteminden büyük ölçüde etkilenmiştir. Bu günlerde Malezya eğitim sistemi artık değişmiştir ve orijinal Ingiliz eğitim sisteminden farklı bir durumdadır. Çok ırklı bir ülke olarak belirli öğrenci gruplarının ihtiyaçlarını karşılamak için farklı düzenlemeler yapılmıştır. Bu nedenle ülke genelinde farklı türlerdeki ilk ve ortaokullar kurulmuştur. Malezya'daki çoğu okul pek çok özel okul olmasına rağmen hükümet tarafından finanse edilir; bazıları tamamen, diğerleri kısmen finanse edilmektedir. Örgün eğitim yedi yaşında başlarken, çoğu ebeveyn çocuklarını çok daha erken yaşlarda anaokuluna gönderir. Çocuklar ortaöğretime geçmeden önce ilkokul veya temel eğitim okullarında altı yıl geçirirler. Onların çoğu, yükseköğrenim düzeyine geçmeden veya istihdamı seçmeden önce orta öğretim düzeyinde 5 yıl daha geçirecektir. Bazı öğrenciler, üniversitelere ve kolejlere girmeden önce (Birleşik Krallık'ın A seviyesine eşdeğer) altıncı sınıfa girer. Böylelikle, Malezyalı çocuklar ortalama 11-12 yıllık ilk ve orta öğretim görürler.

Bu gelişme yıllarında 5.000.000'dan fazla Malezyalı okul çocuğu, günün üçte birinden fazlasını okulda geçirmektedir. Araştırmalar, bu çocukların sosyalleşmesinde okul ortamının mutlaka önemli bir rol oynadığını göstermiştir (Moore-Polanco ve Raghavan, 2006). Çocukların çoğu üretken ve okul sisteminden incinmemiş yurttaşlar olarak ortaya çıkarken, birçoğu geleceklerini etkileyen olumsuz deneyimler yaşadı. Dünyadaki tüm okul 
sistemleri değişmez bir şekilde kabadayılık, okul terki ve diğer anti sosyal davranışlardan adil bir pay alırken Malezya okulları da bundan müstesna olamadı.

Bu ekonomik gelişmeler büyük ölçüde olumluyken Malezya birçok sosyo-ekonomik zorlukla karşı karşıya kaldı. Yoksulluk cepleri hala mevcuttur ve hızlı kentleşme insanlar arasındaki gelir eşitsizliği uçurumunu genişletmiştir (Frost ve Sullivan, 2013; Dünya Bankası, 2014). Artan yaşam maliyeti dışında gelir eşitsizliği, nüfusun yaşlanması, uyuşturucu bağımlılığı ve göçmen işçiler gibi sorunlar, Malezya'nın karşılaştığı diğer zorluklardır.

\section{İslam ve Sosyal Hizmet}

Sosyal hizmet mesleği, toplumun karşılaştığı sorunlar açısından çok önemli olup onlara çözüm bulmaya katkıda bulunmak bakımından da olmazsa olmaz bir meslek türüdür ve birçok zorlukla dolu bir toplumda yaşayan bireylerle ilgilenir. Sosyal işlevsellik, toplum içinde bu koşulların yaratılması ve o toplumun üyeleri için daha tatmin edici bir yaşam tarzı olasılığını artıran bu kapasitelerin geliştirilmesi olarak tanımlanabilir. Uygulanabilirliği ve etkililiği bakımından inanç ve din dâhil olmak üzere sosyal organizasyona ve kültürel değerlere büyük ölçüde bağlıdır. Bu hususları göz önünde bulundurarak bir yaşam biçimi olan İslam'ın, dindarlar ve bireylerin "sosyal hizmet" uygulamaları üzerinde kesinlikle önemli bir etkisinin olduğu söylenebilir.

İslam geleneği temel olarak üç kaynak: (a) Kur'ân-ı Kerîm, (b) Sünnet (Hz. Peygamber'in sözleri ve davranışları) ve (c) İçtihat (dindar âlimlerin yorumu) tarafından belirlenir. İslami bakış açısına göre dünya, var olan ve var olmaya devam eden çok çeşitli ama birbiriyle bağlantılı gerçekliklerin bir toplamıdır. Gerçeklik, ırksal gruplamaları, sosyal sınıfları açığa çıkarırken, İslam bu tür sınıflandırmalara karşı uyarır ve renk, sosyal sınıf, inanç veya fikir temelindeki ayrımcılığı yasaklar. Ümmet (cemaat) kavramı tüm İslami törenlere, geleneklere ve cemaat yaşamına nüfuz eder. Tüm insanlar eşit bir şekilde yaratılmıştır ve soylarına bakılmaksızın eşitlik ve adalete dayalı olarak Tanrı'nın gözünde eşittirler. "Adâlet" kavramı, sosyal hizmet değerlerinin ayrılmaz bir parçasıdır. İslam'da bu kavram defalarca ve kuvvetle gündeme gelir - "Allah size, emanetleri mutlaka ehline vermenizi ve insanlar arasında hükmettiğiniz zaman adaletle hükmetmenizi emrediyor" (Kur'ân, 4: 58). Bu adalet, toplumsal düzenin ve sivil toplumun dayandığı bir temeldir ve Kur'ân'da açıkça ifade edilmektedir ki: "Ey iman edenler! Kendiniz, ana babanız ve en yakınlarınızın aleyhine de olsa Allah için şahitlik yaparak adaleti titizlikle ayakta tutan kimseler olun" (Kur'ân, 4: 135). Elbette ki bu kavramlar, sadece sosyal hizmet değerlerini değil aynı zamanda küresel olarak hukuk sistemini de etkilemiştir (Khan, 2008).

Zira güçlü bir imana sahip olan mümin, karşılığında çeşitli sosyal yükümlülükler getirir. Hz. Peygamberimiz (sav), "Komşusu açken tok yatan bizden değildir" diye buyurmuştur. Bu bakış açısına göre insanlığa hizmet etme eylemi, Kur'ân'da ve sünnette, özellikle de muhtaç olanlar için bir diğer önemli kavram ve konudur. Aşağıda birbirlerine yardım etmeyi teşvik eden Kur'ân ve sünnetten daha fazla kanıt sunulmaktadır.

Kur'ân'da düşük sosyo-ekonomik statüye sahip ve muhtaç insanların maddi durumuna özen göstermeyi teşvik eden çok sayıda âyet bulunmaktadır. Diğer ayetlerin yanı sıra şu ayetleri göstermemiz mümkündür: "Onlar, seve seve yiyeceği yoksula, yetime ve esire yedirirler. Yedirdikleri kimselere şöyle derler: "Biz size sırf Allah rızası için yediriyoruz. Sizden bir karşılık ve bir teşekkür beklemiyoruz" (Kur'ân, 76: 8-9). Başka bir ayette Allah şöyle buyurmaktadır: "iyilik, yüzlerinizi doğu ve batı taraflarına çevirmeniz(den ibaret) değildir. Asıl iyilik, Allah'a, ahiret gününe, meleklere, kitap ve peygamberlere iman edenlerin; mala olan sevgilerine rağmen, onu yakınlara, yetimlere, yoksullara, yolda 
kalmışa, (ihtiyacından dolayı) isteyene ve (özgürlükleri için) kölelere verenlerin; namazı dosdoğru kılan, zekâtı veren, antlaşma yaptıklarında sözlerini yerine getirenlerin ve zorda, hastalıkta ve savaşın kızıştığı zamanlarda (direnip) sabredenlerin tutum ve davranışlarıdır. İşte bunlar, doğru olanlardır. İşte bunlar, Allah'a karşı gelmekten sakınanların ta kendileridir" (Kur'ân, 2: 177). Kur'ân'ın başka bir ayetinde ise Allah-u Teâlâ şöyle buyurmaktadır: "Ey iman edenler! Kazandıklarınızın iyilerinden ve yerden sizin için çıkardıklarımızdan Allah yolunda harcayın. Kendinizin göz yummadan alıcısı olmayacağınız bayağı şeyleri vermeye kalkışmayın ve bilin ki Allah, her bakımdan zengindir, övülmeye layıktır" (Kur'ân, 2: 267).

Verilen hizmetler sadece maddi nitelikte değildi, zira Hz. Peygamber, zor durumda kalan ashabına yoksulluklarında sabırlı olmalarını tavsiye ederek onları teselli ederdi. Riyazeti vaaz ederek insanlara Tanrı'dan büyük ödüller vaat etti (Johari, 2015). Dahası, Hz. Peygamber hastaları bizzat ziyaret eder ve halkın genel maddi durumunu soruştururdu. Bu etkinlikler, bir sosyal hizmet uzmanı veya sosyal eğitimcinin en ayırt edici görevlerinden biri olan danışmanlıktaki motivasyonuyla dolu bir anlam kazanmaktadır (Johari, 2015).

İslam'ın öğretileri, insanları kötülük ve fenalıktan korumayı amaçlar. Bu hedeflere adalet ve yardımseverlik çerçevesinde ulaşılmalıdır. İslam, dürüst bir toplum yaşamına da büyük değer verir. Cuma günlerinde câmide kılınacak mecburi cuma namazı olmak üzere çok sayıda örnek verilebilir. Bu ibadetin kendisi, Kur'ân'da 31:13 ayetiyle ayrı olarak gösterilmiştir ki bireylere ve gruplara (yeryüzünde) kibirlilik yapmaktan kaçınmayı, başkalarına karşı iyiliği emretme ve eşitsizliği ortadan kaldırmayı emreder.

İslam, yardım almadan üstesinden gelemeyecek sayısız sorunla karşılaşan birçok kişinin olacağını kabul eder. Onlar, bilgili ve deneyimli kişilerin yardımlarına ihtiyaç duyarlar. Eşitlik ve adalet kavramlarına rağmen nüfusun bir bölümü temel sosyal haklardan mahrum ve hatta ötekileştirilmiş olarak kalır. Hâlbuki varlıklı ve zengin kişilerin dikkatini ve cömertliğini hak ediyorlar. Kur'ân'da "Mallarında (yardım) isteyen ve (iffetinden dolayı isteyemeyip) mahrum olanlar için bir hak vardır" diye buyurulmuştur (Kur'ân, 51: 19). Bütün müminlerden muhtaç ve fakirlere hayır, sadaka, fitre ve zekât vermeleri istenir. Ancak İslam, kimin hayır, fitre ve zekât almaya uygun olduğunu ve ayrıca bu sadakaların kullanılabileceği veya kullanılamayacağı amaçları da belirler. Hz. Peygamber, "Verici, bağışta ne kadar iyiliğin olduğu bilseydi, bir dilenciyi asla reddetmez, dilenci de dilenmenin ne kadar kötü olduğunu bilseydi, sadaka için asla elini uzatmazdı" diye buyurmuştur.

İslam'ın beş şartı vardır; şehâdet etmek, namaz kılmak, zekât vermek, oruç tutmak ve hacca gitmek. Bu beş şart, Müslümanın iyi ve ahlaki bir varlık geliştirmesine yardımcı olacak mânevi yapılar olarak görülür. İslam inancının ve ibadetlerinin şartları, özellikle Müslüman topluluk içinde sosyal hizmet için önemli çıkarımlara sahiptir (Al-Krenawi ve Graham, 2000). İslam'ın öğretileri ile temel sosyal hizmet değerleri arasında insanlık onuru, sosyal adalet, muhtaçlara yardım etme ve dürüstlük gibi çarpıcı bir benzerlik mevcuttur. Ayrıca baskı karşıtı sosyal hizmetin ana ilkeleri i̇slami öğretilerle oldukça uyumludur (Mullaly, 2002; Turner, Cheboud, Lopez ve Barise, 2002).

Ancak İslam'daki maneviyat, ana akım sosyal hizmetteki baskın bakış açısından önemli ölçüde farklıdır (Van Hook, Hugen ve Aguira, 2001). İslam'da maneviyat, insan ihtiyaçlarının başka bir boyutu olmanın ötesine geçer. İslam, manevi, fiziksel, bilişsel, psikolojik ve sosyal intiyaçların karşılanması konusunda rehberlik sağlar (Barise, 2004). Böylece maneviyat, insan intiyaçlarının birbiriyle ilişkili diğer tüm boyutlarının temelini oluşturur. Bu nedenle sosyal hizmet uzmanlarının İslam'ı sadece kuralları ve düzenlemeleri olan bir din olarak değil, ad-deen olarak anlamaları önem arz etmektedir. Dünya çapındaki 
Müslümanlar, kültürel farklılıklara ve küçük farklara rağmen İslam'ın öğretileriyle birbirlerine bağlıdırlar. Farklı olan şey ise o toplumun kendi görevlerini yerine getirme kapasitesi ve istekliliğidir. Bu kapasite ve isteklilik, iki ana değişken: inanç ve ekonomiden etkilenir. Yöneticiler de dâhil olmak üzere Malezya nüfusunun \%60'ından fazlası Müslümandır. Devlet adamları, ihtiyacı olanlara yardım etmeye yönelik Kur'ân'ın emirlerinin farkındadırlar ve ülkenin ekonomik gücü de bu yardımları karşılamıştır. Yardımlar, dini idareler, zekât kurumu, İslami STK'lar ve en önemlisi câmiler gibi çeşitli kurumlardan gelir.

\section{Malezya'daki Profesyonel Sosyal Hizmete Genel Bakış}

Malezya'da profesyonel sosyal hizmetin tanıtımı, bazı Batılı benzerlerinin aksine 1946'da ülkede Malezya Sosyal Refah Dairesi'nin (DSWM) kurulduğu II. Dünya Savaşı'ndan sonra gerçekleşti (Norani, 2012). Malezya Sosyal Hizmet Çalışanları Derneği'ne (MASW) göre sosyal hizmet, bireylerin, ailelerin, grupların ve toplulukların optimal sosyal işleyişini kolaylaştırmak için bir bilgi, değer ve beceriler kuruluşu tarafından yönetilen "ülke içindeki" bir meslek olarak tanımlanmaktadır. "Ülke içi" terimi tam anlamıyla kabul edilmemelidir, zira işçilerin tamamı olmasa da çoğu Batı'da eğitilmiştir, bu nedenle Batı'nın bilgi birikimine (teoriler, kavramlar, etik kuralları ve felsefe) sahiptirler. Meslek, kolaylaştırma sürecinde danışanların normal sosyal işlevlerini eski haline getirmek ve problem çözme kapasitelerini geliştirmek ve dirençlerini güçlendirmek amacıyla biyopsikososyal bir yaklaşım uygulayacaktır (DSWM, 2012). Meslek aynı zamanda sosyal değişime ve gelişime katkı olarak yorumlanır. Bu tür katkı, sosyal politika ve yasaların çıkarılması, sosyal hizmetler ve insanların ihtiyaçlarına cevap veren diğer programları desteklemeyi içerebilir (MASW, 2012).

Sosyal hizmet, Malezya'da 60 yıldan fazla bir süredir uygulanmaktadır, ancak ciddi bir şekilde düzenlenmemiştir, bu da sosyal hizmet uzmanlarının mesleki hesap verebilirliği, etik ve yeterliliği sorunlarına yol açmaktadır. Yönetmelik, eğitimli sosyal hizmet uzmanlarının işe alınmasını, kayıt ve ruhsatlandırılmasını ve uzmanlıklarının artırılmasını sağlayacaktır ve ayrıca Malezya sosyal hizmet uygulamalarını ve eğitimini küresel standartlara yükseltecektir (DSWM, 2012). Malezya Sosyal Refah Dairesi, Kadın, Aile ve Toplum Kalkınma Bakanlığı (MWFCD), Malezya Sosyal Hizmet Çalışanları Derneği ve Birleşmiş Milletler Çocuk Fonu (UNICEF) ile birlikte yetkinliğe dayalı uluslararası uygulamalarla sosyal hizmette yeni bir profesyonelliği teşvik etmektedir. Bu girişim, Malezya'nın 2020 yılına kadar gelişmiş bir ülke olma hedefine meydan okuyabilecek giderek karmaşıklaşan sosyal sorunlara yönelik sosyal hizmet müdahalelerini geliştirmeyi amaçlamaktadır (DSW, 2012). Kadın, Aile ve Toplum Kalkınma Bakanlığı, bu girişimi gerçekleştirmek için Malezya hükümetine aşağıdaki birkaç teklifi sundu ve bunlar 2010 yılında onaylandı:

1. Sosyal hizmet uygulaması ve eğitimi için Ulusal Yeterlilik Standartlarının oluşturulması;

2. Yeterlilik Standartlarını uygulamak için bir Sosyal Hizmet Uzmanı Yasası'nın çıkarılması;

3. Sosyal hizmet uygulayıcıları ve eğitimcilerinin yeterliliklerini düzenlemek için Yasaya göre bir Sosyal Hizmet Konseyi'nin kurulması;

4. Yükseköğrenim kurumlarında sosyal hizmet eğitimi için standartlaştırılmış programların sunulması;

5. Kamu Hizmeti İdaresi'nin (PSD) kamu sektörüne nitelikli sosyal hizmet uzmanları istihdam etmesi ve 
6. Malezya Sosyal Enstitüsü'nün geliştirilmesi ve sertifika ve diploma düzeylerinde sosyal hizmet kursları sunmak için diğer akredite eğitim enstitülerinin kurulması (DSW, 2012).

Bu girişim, geleneksel gayri resmi bakım alanında azalan kapasiteyi ele almak ve hızla değişen yerel toplumun çeşitli psikososyal sorunlarını değerlendirmek için tasarlanmıştır. Bu girişim, Malezya sosyal hizmet uygulama ve eğitim tarihinde bir dönüm noktası olarak kabul edilir ve İdare, Bakanlık ve Malezya Sosyal Hizmet Çalışanları Derneği'nin tüm vatandaşların güvenliği ve korunmasına yönelik taahhüdünü yansıtır (DSWM, 2012). Girişim aynı zamanda bu mesleği gelişmiş ülkelerdeki uygulamalara uygun hale getirmeyi hedeflemektedir.

Malezya'da uzun yıllardır "sosyal hizmet uzmanları" herhangi bir örgün eğitim veya üniversite diploması olsun veya olmasın farklı sosyal ortamlarda çalışıyorlar (Fattahipour ve Hatta, 1992). Bunlar sosyal yardım görevlileri, çocuk koruma memurları, gözetim memurları, hapishane görevlileri, uyuşturucu rehabilitasyon görevlileri, tıbbi sosyal hizmet görevlileri, sosyal hizmet eğitmenleri, bağımsız sosyal hizmet danışmanları, sosyal hizmet öğretim görevlileri, araştırmacılar ve hükümet dışı sosyal yardım çalışanları olabilir.

Malezya Sosyal Refah Dairesi, günümüzde sosyal hizmet uzmanlarını istihdam eden en büyük kurumdur. Daire, bazı görevlileri sosyal hizmet alanında lisans derecesine sahip olmaları nedeniyle sosyal hizmet uzmanı olarak kabul etti. Ancak 3.000'den fazla çalışanın yalnızca üçte biri eğitimli ve sosyal hizmet uygulamasında yer almaktadır. Diğerleri ya teknik, yardımcı ya da profesyonel personeldir (DSWM, 2012). Öte yandan Malezya Sosyal Hizmet Çalışanları Derneği'nin 160'tan fazla üyesi bulunmaktadır, ancak hepsi uluslararası mesleki standartta tanımlandığı gibi sosyal hizmet uzmanı değildir.

\section{İslami "Sosyal Hizmet" Faaliyetlerine Genel Bakış}

Hz. Peygamber (sav) zamanında câmi sadece ibadet yeri olarak değil, aynı zamanda eğitim ve öğretim merkezi, sosyal faaliyetler, toplum geliştirme merkezi, bilgi merkezi, yargı merkezi, iletişim merkezi, toplum etkileşim merkezi, tedavi ve acil servis, rehabilitasyon merkezi ve sanat merkezi olarak da işlev görüyordu. O zamandan beri câmiler ve musalla (küçük ibadet yeri) hâlâ Müslüman cemaati için önemli bir yer olarak görülmektedir.

İslam, Malezya'nın resmi dinidir ve ülkedeki İslami meseleleri araştırmakla yükümlü devlet kurumları bulunmaktadır. Diğerlerinin yanı sıra federal düzeyde İslami işleri yöneten ana kurum olarak Malezya İslami Kalkınma İdaresi (JAKIM) ve Malezya İslami İşler Ulusal Konseyi sekreterliği bulunmaktadır. Tüm câmilerin idaresi, ilgili iller Dini Müdürlüklerine bağlıdır. Câmi, ekonomik açıdan bakıldığında ekonomik krizin ele alınmasında potansiyel bir kurum olarak hareket ediyor gibi görülür. Câmilerin fonunun ana kaynağı, haftalık Cuma cemaat namazı sırasında insanların katkılarından kaynaklanır. Diğer gelir kaynakları ise kurumsal bağıştan gelir.

\section{Malezya'daki Câmiler ve Üstadlar}

Malezya'da câmi sayısı 6.321 ve toplam üstad sayısı 6.000'in üzerindedir. Malezya'daki câmiler altı türe ayrılabilir: ulusal câmiler, devlet câmileri, bölge câmileri, kurumsal câmiler, karye (küçük köy/cemaat) câmileri ve Cuma câmileri. Malezya'daki büyük câmiler sadece ibadet için kullanılmıyor, aynı zamanda Kur'an okuma dersleri, hastane ziyaret programı, bekar anneler için programlar, sağlık programları ve cenaze hazırlık programları gibi diğer katma değerli hizmetler ve olanaklar da sağlıyor. Câmi ayrıca arsa ve bina gibi varlıklar şeklinde hayır ve vakıf toplama yeri olarak da kullanılmaktadır. 
İmamın (cemaat namazını yöneten din adamı) seçimi için en önemli kriter, Kur'ân'ı doğru okuyabilme ve İslam hukukunun temelleri hakkında bilgi sahibi olabilmesidir. Adaylar genellikle üniversite mezunları, diploma veya lise diploması sahipleri arasından atanır. Câmilerin diğer görevlileri ise İmam Besar (baş imam), hatip (Cuma hutbesi okuyucusu), bilâl (müezzin) ve tok siak'tır (câmi güvenlik görevlisi). Hükümet tarafından atanan bir imam genellikle maaş olarak Malezya İslami Kalkınma İdaresi tarafından ödenecek olan 450 ve eyalet hükümeti tarafından ödenecek 200 Malezya ringiti ödeneği alır.

\section{Amaç}

Çalışmanın genel amacı câmilerin, kurumların ve üstadların "sosyal hizmet" alanında gerçekte neler yapmakta olduklarını olabildiğince nesnel ve deneysel olarak öğrenmek ve kayıt altına almaktır. Spesifik hedefler aşağıdaki gibidir:

1. Câmilerin, kurumların ve üstadların ve genel Müslümanların "sosyal hizmet" alanında gerçekte ne yaptıkları hakkında bilgi edinmek.

2. Üstad, imam veya Müslümanların İslami "sosyal hizmet" faaliyetlerine katılma nedenlerini araştırmak.

\section{Metodoloji}

\section{Araştırma Tasarımı}

Bu keşif amaçlı araştırmada hem nicel hem de nitel veri toplamayı kullanan karma bir yöntem yaklaşımı kullanılacaktır. Nitel yaklaşım (yarı yapılandırılmış mülakatlar), birinci ve ikinci araştırma amaçlarını ele almak için kullanılmıştır. Topluma hizmet sağlamada kullanılan demografik verileri ve süreçleri belirlemek için Malezya'nın kuzeyindeki Keda ilindeki Kubang Pasu ilçesindeki (haritaya bakınız) imamlar arasında basit bir anket uygulandı. Veriler, belge araştırmalarıyla da toplandı. Keda nüfusunun yaklaşık \% 77'si Müslümandır.

\section{Örnekleme}

Bu araştırma, kullanılan araştırma yöntemlerine dayalı olarak iki tür katılımcı içermektedir.

1. Niteliksel yöntem: İncelenmek üzere üç kurumu temsil eden üç katılımcı seçildi yani Persekutuan ilindeki bir câmii imamı, Kubang Pasu ilçesinden bir zekât memuru ve Nusret Vakfı (Yayasan Nusrah) başkanı.

2. Nicel yöntem: Kubang Pasu ilçesinde 72 câmi bulunmaktadır ancak araştırmaya Kubang Pasu ilçesi câmilerinden sadece 20 imam katıldı.

\section{Araştırma Araçları}

Veri toplama süreçleri iki aşamadan oluştu. Illk olarak İslami "sosyal hizmet" faaliyetlerini ve bu faaliyetlere dâhil olma nedenlerini araştırmak için yarı yapılandırılmış bir mülakat programı kullanıldı. Katılımcılara, hedef kitle ve hizmet alanların sayısı, günlük faaliyetler ve uygulamalar, yönetim (personel sayısı, bütçe bilgileri, fikir, misyon ve ilkeler) ve dâhil olma nedenleri ile ilgili sorular soruldu.

Nicel araştırma için veri toplama aracı iki kısımdan oluşmaktadır. A kısmı, yaş, resmi din eğitimi ve çalışma deneyimi gibi demografik sorulardan, B kısmı da hizmet / müdahale sağlama süreçlerine ilişkin 12 maddeden oluşmaktadır. Araç, 2005 yılında Barise tarafından önerilen İslami Sosyal Hizmet Uygulama Modeli temel alınarak uyarlanmıştır. Anket beş puanlık bir ölçekten oluştu ( 1 = "Asla" ila 5 = "Çoğu zaman"). Aylık bir toplantıya 
katılan 20 imamdan, muhtaç kişilere evlilik meseleleriyle ilgili hizmet veya müdahalelerde bulunmadaki deneyimlerini ve uygulamalarını paylaşmaları için bir dizi anketi yanıtlamaları istendi.

\section{Veri Analizi}

Nitel veriler için betimsel analiz kullanılmıştır. Nicel veriler için ise verilerin analizi için SPSS istatistiksel yazılımın 19. sürümü kullanılmıştır.

\section{Araştırma Bulguları}

Araştırma bulguları iki bölüme ayrılmıştır. 1. bölüm, câmilerin, kurumların, üstadların ve Müslümanların "sosyal hizmet" alanında gerçekte ne yaptıkları hakkında bilgi edinmeye yönelik birinci numaralı araştırma sorusunun bulgularını ifade etmektedir. Bu bölüm amaç, hedef nüfus ve hizmet alanların sayısı, günlük faaliyetler ve uygulamalarla başlayacaktır. 2 . bölüm ise Müslümanların bu faaliyetlere katılma nedenlerini açıklamaktadır.

\section{Bölüm: İslami "Sosyal Hizmet" Faaliyetlerinin Örnekleri}

İslam'da çağdaş sosyal hizmete benzeyen birçok sosyal yardım faaliyeti mevcuttur. Bu çalışmanın amacı için rapor edilecek ve tartışılacak dört durum bulunmaktadır.

\section{Örnek 1: Persekutuan il Câmii}

Bu câminin sadece ibadet için değil, aynı zamanda Kur'ân okuma kursları, hastane ziyaret programı, bekar annelere yönelik programlar, sağlık programları, cenaze hazırlık programları gibi diğer hizmetleri de sağladığını söylemek kayda değerdir. Câmi aynı zamanda arazi ve bina gibi varlıklar biçiminde hayır ve bağıs toplama yeri olarak da kullanılmaktadır. Diğer programlar, hayır işleri ve sosyal hizmetler, beşeri sermaye geliştirme ve hastaların tedavisi için para kaynağı yaratmayı içerir.

Vakıf programı ile An-Nur Wakaf Klinik Hastanesi olarak bilinen zincir klinikler aracılığıyla yoksullara sağlık hizmetleri sunulmaktadır. Bu programda farklı hastanelerden gelen bir sağlık ekibi kan kolesterolünü, kan şekeri seviyesini, tansiyonu ve diğer bazı kontrolleri uygulamaktadır. Şu anda, tıp uzmanı aynı zamanda çeşitli yaygın hastalıklar ve İslam'ın sağlık sorunlarını hafifletmedeki rolü hakkında da konuşmaktadır.

Wilayah Persekutuan camiinde, aileleri için iyi ve sağlıklı yemekler pişirmek isteyen hanımlar için yemek pişirme kursu düzenlenmektedir. Cami aynı zamanda çevre konusu ile de ilgilenmektedir. Farkındalık ve sosyal yardım programları ile ekolojik sistemin korunmasında etkin rol oynamaktadır.

Ahlak İslam'da sıkça vurgulanmaktadır. Hz. Muhammed (sav) hastaları ziyaret etmeyi, açları doyurmayı ve esiri serbest bırakmayı tavsiye etmiştir. Bu nedenle, Wilayah Persekutuan cami topluluğu, Kuala Lumpur ve Klang Vadisi çevresindeki hastanelere düzenli ziyaretler yapmıştır. Ziyaretler sırasında hem Müslüman hem de gayrimüslim hastalara hediyeler dağıtılmıştır.

Bir diğer ortak program olarak ise iftar (oruç ayı Ramazan'da güneş batarken orucun açılması) bir ibadet çeşidi olarak kabul edilir. Her gün büyük bir iftar programı düzenlenmektedir. Son olarak, bir defin hizmeti bulunmaktadır. Bir saygı biçimi ve cinsiyet kuralları gereği olarak, yıkama ve kefenleme normalde ilgili cinsiyete özel kapalı bir alanda yapilır.

Örnek 2: Kubang Pasu Zekât Toplama Ofisi 
Zekâtın toplanması, İslam'ın en önemli sosyal hizmetleri arasında bulunmaktadır. Zekât, Kuran'da öngörüldüğü gibi hak sahibi olanların menfaatine belirli bir servetten belirli bir miktar (en az\% 2,5) verilmesi olarak tanımlanır. Zekât kriterlerini karşılayan tüm Müslümanlar ödemekle yükümlüdür. İslam ayrıca, müminlerin ihtiyaç duyulduğunda başkalarına yardım etmesini de vurgulamaktadır. Sosyal hizmet alanında yerine getirilen görevlere neredeyse benzer olan bu emir, Kuran'da şu şekilde geçmektedir: (2:177) “(Ey ibadet edenler!) İyi ve erdemli olmak (yalnızca) yüzlerinizi doğu ve batı tarafına çevirmeniz değildir. Fakat iyi ve erdemli (muttakî) kişi; Allah'a, âhiret gününe, meleklere, Kitab'a (Kur'an'a) ve peygamberlere inanıp malı(nı), sevgisine rağmen (Allah rızası için) akrabaya, yetimlere, yoksullara ve yolda/sokakta kalmışlara, dilenenlere ve boyunduruk altında bulunanlara (kurtulmaları için ihlasla) veren, namazı dosdoğru kılan, zekâtı veren, ahitleştiği zaman sözlerini yerine getiren, sıkıntıda, hastalıkta ve savaşın şiddetlendiği anda sabredendir. İşte (imanlarında, yaptığı iyilik ve taatte) doğru olanlar onlardır. Ve takvâya erenler de onlardır.

Malezya'da, zekât toplama merkezi, toplama işlemini yöneten ve nitelikli ve kayıtlı alıcılara zekât dağıtımı sürecini yöneten bir kuruluştur. Her eyaletin kendi zekât toplama ofisi bulunmaktadır. Bu çalışmanın amacına uygun olarak, Malezya'nın kuzey eyaletinde bulunan Kubang Pasu Zekât Toplama Ofisi bir örnek olarak incelenmektedir.

Kubang Pasu, Kedah Eyaleti'nin 12 ilçesinden biridir ve 94.596 hektarlık arazi büyüklüğü ile üçüncü en büyük ilçedir. Bölge iki federal / parlamento seçim bölgesine ve dört eyalet seçim bölgesine ayrılmıştır; illçe toplamda 71 kariah (mahalle) olmak üzere 18 mukimden oluşmaktadır. Kubang Pasu ilçesi nüfusunun 89.709 erkek ve 96.557 kadın olmak üzere 186.265 kişi olduğu tahmin edilmektedir. İlçe nüfusunun \%80'i Müslümandır, \%20'si ise diğer inançlara ve dinlere aittir.

Kubang Pasu Zekât Ofisi (KPZO), Kedah Eyaleti Zekât Bakanlığı tarafından yönetilen eyaletteki on iki zekât ofisinden biridir. Ofis bir Zekât Memuru tarafından yönetilmekte ve dini geçmişi olan birkaç kâtip tarafından desteklenmektedir. Ana görevleri olabildiğince çok nitelikli alıcı (asnaf) bulmak ve tüm zekât başvurularını denetlemektir. Başvuru sahibi yasanın öngördüğü şekilde zekât almaya hak kazanırsa, ofis en uygun yardımı belirleyecek ve sağlayacaktır. Sağlanan yardım, maddi formlar veya hizmetler gibi, yalnızca finansal yardım dışında başka şekillerde olabilir. KPZO'nun sunduğu dört ana tür yardım programı vardır; Yoksullar için Aylık Mali Yardım, Yoksullar için Aylık Gıda Yardımı, Yaşı Bakım Merkezlerinde Yaşlılar için Aylık Gıda Yardımı ve Yaşlı Bakım Merkezi İnşaatı Yardımı. Başvuru sahiplerinin ihtiyaçlarına ve gereksinimlerine göre başka yardım türleri de mevcuttur; örneğin KPZO'nun nitelikli başvuru sahiplerine üniforma, kitap ve eğitim aksesuarları sağladığı İlkokul Yardım Programı.

Zekât Ofisi (ZO), Kubang Pasu bölgesindeki her camiden imamlarla yakın işbirliği içinde çalışmaktadır. Tüm imamlar amil (ZO için zekât toplayıcıları) olarak atanmıştır ve qaryah (cemaat) arasında ihtiyacı olanları tespit etme sorumluluğu verilmiştir. İmamlar burada hayati bir rol oynamaktadırlar, zira ihtiyaç duyulması halinde qaryah üyelerinin aile fertlerinden sonra yardım istenebilecek bir sonraki kişi onlardır.

Kedah Eyaleti Zekât Departmanı'nın tek fon kaynağı eyaletteki Müslüman cemaatinden gelmektedir. Koşulları karşılayan her Müslüman, iki tür zekât ödemesi yapmak zorundadır. Birincisi, hane reisinin tüm aile üyeleri adına ödediği zorunlu sadaka olan Fıtır Sadakası veya Fitredir. Bu zekât Ramazan ayı boyunca ödenir ve bitiş dönemi, İslami Şevval ayının ilk günü Ramazan Bayramı namazının başlamasından öncedir. Kedah Eyaletinde Fitre oranı hanedeki kişi başına 7,00 RM'dir. Fitre ödemesinin tahsilini en üst düzeye çıkarmak için 
KPZO, alışveriş kompleksleri gibi halka açık yerlerde ödeme sayaçları kurmuştur veya kişiler, kuruluş tarafından atanan amillere ödeme yapabilirler. 2015 yılında Kubang Pasu Mahallesi'ndeki 74 camiden 351 kişi amil olarak atanmıştır. Kedah Devlet Zekât Komitesi Sekreteri Dato Şeyh Gazali Yakup'a göre ödeme kısa mesaj sistemi (sms) ile de yapılabilmektedir.

İkinci zekât türü, bir bireyin sahip olduğu servet veya mülk miktarına bağlı olarak bir yıl boyunca birikmiş servet üzerinden ödenmesi zorunlu olan Malın Zekâtı'dır (Zekât-ül Mal). $\mathrm{Bu}$, altın ve gümüş takılar, stoklar, ürünler, nakit para, hayvancılık, tarımsal ürünler gibi malları içermektedir. Vergi veya harç gibi herhangi bir kesinti yapıldıktan sonra zekât için ödenmesi gereken asgari tutar, kişi başına, bir yıllık bir süre boyunca\% 2,5 oranında 10.000 RM'dir. Asgari şart yerine getirilemiyorsa, birey zekât ödemek zorunda değildir. Zekât için ödenmesi gereken asgari altın / gümüş takı ağırlığı, altının bugünkü piyasa değerinin 85 gram katı zekât oranı olan\% 2,5'tir. KPZO, ödenecek zekât miktarının hesaplanmasına da yardım etmektedir.

Zekât-ül Mal ödemesi, ofislerinde, özel olarak tayin edilmiş amiller tarafında aylık ücret kesintileri ile yapılabilir. Özel olarak tayin edilen amiller karmaşık Zekâtül Mal hesaplamaları yapmak üzere eğitilmişlerdir. 2015 yılında Kubang Pasu Bölgesi'nde mülk özel amili olarak atanan 10 kişi ve MADA (Muda Tarımsal Kalkınma Ajansı), pirinç depolama ve üretimine ilişkin zekât ödemesi için pirinç amili olarak atanan tek kurumdur. Devlet memurları, Kedah Devlet Zekât Dairesi web sitesinden indirilebilecek başvuru formunu doldurarak zekât ödemesini bir ücret kesintisi ile birlikte yapabilirler.

Kubang Pasu Zekât Ofisi, en büyük zekât toplama kaynağının gelir ve ücretler üzerindeki zekâttan geldiğini belirtmiştir. Ancak zekât memuru, Kubang Pasu bölgesinin, eyaletteki en büyük pirinç tarlalarına sahip olduğu ve birçok Müslüman pirinç üreticisinin zekâtlarını ödediği için Kedah Eyaletinde çeltik / pirinç üzerindeki en büyük zekât tahsilatına sahip olduğunu söylemiştir. (bkz Tablo 1)

Tablo 1:

Aralık 2014 ile Ocak 2015 arasındaki Zekât Tahsilatı (8 Ocak 2015 itibariyle)

Zekât Tahsilatları Aralık 2014 Ocak $2015 \quad$ Toplam

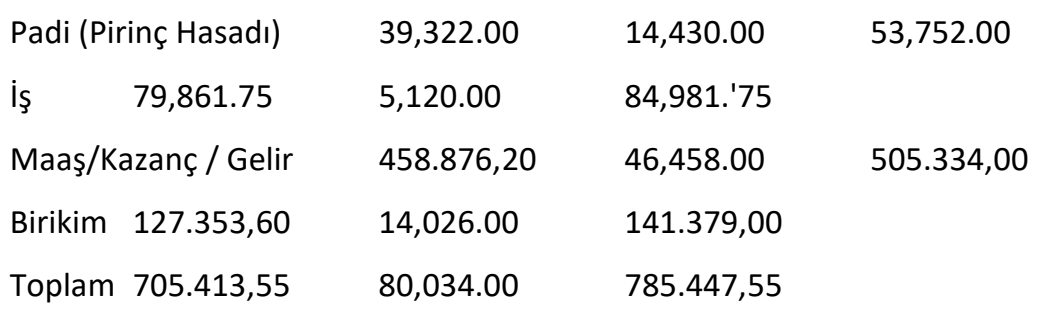

Zekât alıcılarına veya asnaflara, şeriatteki tanımlarını karşılıyorlarsa ve KPZO gerçek koşullarından tatmin olduğunda zekât parası veya başka bir yardım sağlanacaktır. Şeriate göre, zekât alıcıları olarak listelenen sekiz tür kişi bulunmaktadır. İslam Hukuku Danışma Kurulu üyeleri 4 Temmuz 1987'de Fakir, Miskin, Fisebilillah, Ibnu Sabil, Muallaf, Rikab, Garim ve Amil'in tanımlarına ilişkin bir karar yayınlamıştır.

- $\quad$ Fakir (Ihtiyaç Sahibi) - Herhangi bir mülk veya mesleğe sahip olmayan veya miktarı kişinin günlük ihtiyaçlarının ve bakmakla yükümlü olduğu kişilerin ihtiyaçlarının yüzde 50'sini karşılamayan başka kaynaklardan gelir elde eden kişi. 
- $\quad$ Miskin (Yoksul) - Bir mesleği olan veya bir tür mülke sahip olan ancak kişinin geliri temel ihtiyaçlarını yeterince karşılamayan ve bakmakla yükümlü olduğu kişileri barındıran kişi.

- $\quad$ Amil - Zekâtın toplanması ve dağıtılması da dâhil olmak üzere işleri yönetmek üzere şahıs veya kuruluş olarak atananlar.

- $\quad$ Muallaf- Yeni Müslüman olan kişiler

- $\quad$ El-Rikab - Kurtarılmış Köleler (modern zamanda geçerli değildir.)

- $\quad$ El-Gârimîn - Kendilerinin, ailelerinin veya bakmakla yükümlü oldukları kişilerin yararına temel ihtiyaçları veya acil çözümler gerektiren topluluğun ihtiyaçlarını karşılamak (örneğin, cami inşaatlarını finanse etme ihtiyacı) için para borcu olanlar

- $\quad$ ibn Sabil (Yolcular) - Kendi kaynaklarından uzakta olan yolcular

- $\quad$ Fisebilillah (Allah yolundakiler) - İslam'ın erdemini ve öğretisini korumak, sürdürmek, yaymak için faaliyetlerde bulunan Müslümanlar

Kubang Pasu Bölgesi'ndeki zekât dağıtımı açısından en büyük alıcılar (2014'te 95 kişi ve 2015 'te 97 kişi ile) yoksul bireylerdir, ardından da (2014'te 56 ve 2015'te 59 kişi ile) fakirler gelmektedir.

Tablo 2

Yardım Türleri ve Alıcı Sayısı Aralık 2014 ile Ocak 2015 arasında (8 Ocak 2015 itibariyle)

Yardım Türleri Aralık $2014 \quad$ Ocak 2015

Mali (Fakir) $\quad 56 \quad 59$

Yiyecek (Fakir) $39 \quad 41$

Mali (Yoksul) $95 \quad 97$

Yiyecek (Yoksul) $57 \quad 57$

Mali (Öğrenciler) 19

Mali (Tedavi) $12 \quad 12$

Mali (Üniversite Bursu) 1

Mali (Yeni ev inşaası) 2

Mali (Ev yenileme) 34

Toplam $484 \quad 291$

\section{Örnek 3: Nusrah Vakfı}

"Sosyal hizmet" faaliyetlerinin bir başka örneği de Nusrah Vakfı'dır. 2010 yılının başında kurulmuş ve özel bir sınırlı işletme olarak tescil edilmiştir. Kurucu Dr. Nadiyah Eliyas, Malezya'daki devlet üniversitelerinden birinde İslami danışmanlık konusunda uzman olan kıdemli bir öğretim görevlisidir. Kendisi vakfın kurulmasının temel sebebinin muhtaç insanlara yardım etmek olduğunu belirtmektedir. Ödenmiş sermaye olarak 1 milyon Malezya Ringitini başarıyla toplamıştır. Ana fon kaynakları, aile üyeleri, yakın akrabalar ve etkili yakın arkadaşların bağışları ve katkılarından oluşmaktadır. Vakıf, vakfın gelişimini, eğitimini ve koordinasyonunu destekleyen küçük bir profesyonel kadroya sahiptir. 
Topluluk üyeleri, Nusrah Vakfı'nın amacına ulaşmasına yardımcı olmaya teşvik edilmektedir. İşe alınan personel dışında, Vakıfta temel olarak iki grup katkıda bulunan kişiler vardır. Birinci grup, mali açıdan durumu iyi olan, ancak zamanını ve enerjisini gönüllü işler yapmak için ayıramayan ve çoğu profesyonel olan kişilerdir. Bunlar vakfın aylık mali hayırseverleridir ve ikinci grup vakfın tüm programlarını yürütmek için gerçekten zaman ve enerjilerini sağlayan gönüllülerden oluşmaktadır. Bu kişiler, kişisel geçimlerini sağlamak için yalnızca küçük bir miktar ödenek alırlar.

Nusrah Vakfı pek çok sosyal faaliyette bulunmuştur. Bunların arasında bekar annelerin gelir elde etmesine yardımcı olmak, gönüllüler için eğitim programı düzenlemek (Sahabat İrsyad - eğitmenler için eğitim programı), Kamboçya'da kurban (inek ve kuzu gibi hayvanların kesilmesi ve etin dağıtılması) faaliyetleri organize etmek ve sel mağdurlarına yardım ve destek sağlamak. Bekar annelerin gelir elde etmesine yardımcı olmak, vakfın sürekli faaliyeti haline gelmiştir. Vakıf, bekar annelere küçük bir işletme girişimini üstlenmeleri için danışmanlık, eğitim, teknik destek ve finansal sermaye sağlamaktadır. Örneğin, önce bekar annelerin listesini hazırlarlar. Ardından, katılımcıların küçük bir işletme girişimine olan ilgisini öğrenmek için görüşmeler yaparlar. Ekim işi veya fırıncılık gibi belirli alanlara ilgi duyan ancak gerekli becerilere sahip olmayanlar eğitime gönderilir. Dersler vakfın kendi eğitmenleri veya bazı durumlarda ilgili eğitmenler veya uzmanlar tarafından verilir. Bazı durumlarda, kullanışlı el işi ürünleri becerisine sahip katılımcılara, girişime başlamak için 1.000 RM'den fazla olmayan küçük bir miktar mali sermaye de verilmiştir. Bekar anne girişimciler daha sonra ürünleri kendi başlarına satma seçeneğine sahip olacak veya malları pazarlamak için vakfın yardımını isteyebilecektir.

Diğer bir yardım yöntemi proje aracığıyla yapılmaktadır. Örneğin, 2014 yılında Malezya'nın Doğu Kıyısı'nda meydana gelen son sel felaketi, geçim kaynaklarını olumsuz etkilemiş, altyapıyı tahrip etmiş ve özellikle Kelantan'da toplum yapısını değiştirmiştir. Ülke tarihindeki en büyük sel felaketinin ardından binlerce insan evlerini kaybetmiştir. Nusrah Vakfı, sonunda kalıcı evler olarak yenilenen 80 temel yaşam alanı sağlamak için girişimlerde bulunmuştur. Başlangıçta kuruluş, 4078 hane için her biri yaklaşık 3000 RM'ye mal olan evlerin temel yapısının maliyetini finanse etmiştir. Kalan birimler ve yapı genişletmeleri finanse edilmiştir ve bu halkın bağışları ve katkılarıyla sağlanmıştır.

Vakıf ayrıca sel mağdurlarına gıda ve ihtiyaç malzemeleri temin etmiştir. Ayrıca, etkilenen bölgelerin yerel liderleri ve topluluklarıyla işbirliği yapmıştır. Kuruluş, mağdurlara yardım sağlamak için civardaki sakinler arasında gönüllüler yetiştirmiştir. Okullarda ve camilerde yardım merkezleri açılmıştır. Vakıf, cemaatin de yardımıyla yardımı zamanında dağıtmayı başarmıştır.

\section{Örnek 4: İmamların yardımı}

Diyanet dairesi ve camiler gibi dini kurumlar, tüm Müslümanlara manevi, sosyal, psikolojik, fiziksel ve bilişsel yönleri içeren hizmetleri sunmada hayati bir rol oynamaktadır. Bu tür hizmetleri uygulama görevi, Diyanet dairesi tarafından atanan ve tanınan üstad veya imam olarak bilinen kişilere aittir. Bu kişiler İslam hukuku alanında profesyonel olarak eğitilmiştir. Dini bilgi ile donatıldıkları için Müslüman toplumda oldukça fazla saygı görmektedirler. Çoğu zaman beş vakit cemaat ve cuma namazlarını camilerde imam olarak kıldırmaktadırlar.

Diyanet İdaresi 1962 Yılı Yasasına göre, cami memuru olarak seçilebileceklerin aşağıdaki koşulları sağlaması gerekmektedir:

a. 21 yaşından büyük olmalıdır. 
b. İyi davranış ve hareketlere sahip olmalıdır.

c. Jawi okuyabiliyor ve yazabiliyor olmalıdır (birçok Arap alfabesine sahip Malay dili)

d. Karyah üyesi olmalıdır.

e. Herhangi bir devlet kurumunda herhangi bir pozisyona sahip olmamalıdır.

f. Siyasete aktif olarak katılmıyor olmalıdır.

g. İslam hukuku konusunda yeterli bilgiye ve Kuran okuma konusunda mükemmel bilgiye sahip olmalıdır.

Üstad veya imam, İslami düzenlemelerin uygulanmasına yardımcı olmak ve ihtiyaç duyulduğunda dini konularda ve sosyal konularda Müslüman topluluğuna yardım etmek için atanan dini yetkilidir. Toplumda özellikle evlilik meseleleri ile ilgili bilgi sağlamada önemli bir rol oynarlar. Sonuç olarak, Kubang Pasu Bölgesindeki imamlar arasında karyah üyelerine hizmet sağlama uygulamalarını kaydetmek için bir anket yapılmıştır. Anket, ankete katılanların sosyo-demografik geçmişiyle başlamakta ve ardından toplum hizmetleri uygulamalarının bir açıklaması ile devam etmektedir.

Tablo 3'e göre, katılımcıların ortalama yaşı 60.95 yaştır (Aralık = 40 ila 74 yıl) ve on dokuz katılımcı evlidir. Ankete katılanların çoğunluğu resmi din eğitimi almıştır ( $n=17)$ ve imam olarak 10 yıldan fazla deneyime sahiptir $(n=14)$.

Tablo 3

Sosyo-demografik Profil

Katılımc bilgileri

Yaş

41-50 yaş $=3$

Deneyim Yılı

$51-60$ yaş $=6$

1 Yıldan az = 2

61 yaş ve üstü $=11$

$1-5 Y_{I} l=2$

( Min $=41$ yaş Maks $=74$ yaş ortalama $=60.95$ yaş $)$

$6-10 Y_{I} l=7$

Medeni Durum

$11-15 Y_{I} l=1$

$15-20 Y_{\mathrm{I}} \mathrm{l}=4$

Evli $=19$

21 Yıl ve üstü $=2$

$\mathrm{Dul}=1$

Belirtilmemiş $=2$

Resmi Din Eğitimi

$\operatorname{Var}=17$

Yok $=3$

Barise (2005), sosyal hizmet süreçlerini İslami dünya görüşü, kavramlar ve yardım etme, problem çözme ve değişim anlayışları ile bütünleştiren bir model önermiştir. Önerilen modele dâhil edilmek üzere seçilen kavramlar; uyanma (Kavme), danışma (İstişare), düşünce (Tefekkür), rehberlik arama (İstihare), hedef ve yol vizyonu (Basiret), isteyerek karar verme (Azim), Allah'a güvenme (Tevekkül), iyi işler yapma (Amel), öz değerlendirme (Muhasebe), öz-izleme (Murakabe) ve Allah'tan yardım isteme (İstiane). Anket ayrıca, topluma hizmet sunarken katılımcılar (yani imamlar) tarafından uygulanan süreçlerin sıklığını bulmaya yönelik soruları da içerir. Daha yüksek ortalama, kullanılan işlemlerin 
daha yüksek aralığını göstermektedir. Tablo 4, ankete katılanların çoğunun uyum oluşturmadan öz-izlemeye kadar yardım süreçlerini uyguladığını göstermektedir. Ve çoğu zaman, katılımcılar müşterilerinden Allah'a güvenmelerini ve sorunlarını çözmede Allah'tan yardım istemelerini talep etmişlerdir.

Tablo 4

Katılımcılar Tarafından Uygulanan İslami Kavramlara Dayalı Süreçlere Yardımcı Olmak

Yardım süreçleri Ortalama

İlişki kurma $\quad 3,95$

Kavme (uyanma veya bilinçli olma) 3,65

İstişare (veri toplama) $\quad 3,35$

Tefekkür (Düşünme veya fikir)

İstihare (Rehberlik) $\quad 3,25$

Basiret (Eylem Vizyonu) 3,3

Azim (İsteyerek karar verme)

Tevekkül (Allah'a güvenmek)

Amel (Eylem) 3,4

Muhasebe (Değerlendirme)

Istiane (Yardım aramak) 4,15

Murakebe (Öz-İzleme) 3,9

\section{Bölüm: Sosyal Hizmet Faaliyetlerine Katılım Nedeni}

Kedah, Kubang Pasu semtindeki 20 camiden 20 katılımcı (imam) kolay örnekleme yöntemi ile seçilmiştir. İslami sosyal hizmet faaliyetlerine katılma nedenleri soruldu. Verdikleri yanıtlara göre, iki ana tema ortaya çıkmıştır. Bunun nedenleri şunlardır:

\section{Sorumluluk (Emanet)}

Insanlar Allah'ın halifesidir. Sadece bir imam olarak değil, bir Müslüman olarak, Allah'a ve diğer insanlara (kendisi, ailesi, ebeveynleri, toplum, çevre ve millet dâhil) karşı sorumlulukları vardır. Ebu Hüraira'nın rivayet ettiği üzere Peygamber Efendimiz şöyle demiştir: "Insanların her bir eklemi için her gün bir sadaka gerekir. İki kişi arasında adâletle hükmetmen sadakadır. Bineğine binmek isteyene yardım ederek bindirmen yahut yükünü bineğine yüklemen sadakadır. Güzel söz sadakadır. Namaz için mescide giderken attığın her adım bir sadakadır. Gelip geçenlere eziyet veren şeyleri yoldan gidermen de sadakadır."

\section{Toplumun İhtiyaçlarını Karşılamak İçin}

İslami öğretilerde iyilik yapmak ve ihtiyacı olanlara yardım etmek zorunludur. Numan bin Beşir'in rivayet ettiği üzere Peygamber (sav) şöyle demiştir: “Allah'ın çizdiği sınırları aşmayarak orada duranlarla bu sınırları aşıp ihlâl edenler, bir gemiye binmek üzere kur'a çeken topluluğa benzerler. Onlardan bir kısmı geminin üst katına, bir kısmı da alt katına yerleşmişlerdi. Alt kattakiler su almak istediklerinde üst kattakilerin yanından geçiyorlardı. 
Alt katta oturanlar: Hissemize düşen yerden bir delik açsak, üst katımızda oturanlara eziyet vermemiş oluruz, dediler. Alt kattakiler su almak istediklerinde üst kattakilerin yanından geçiyorlardı. Alt katta oturanlar: Hissemize düşen yerden bir delik açsak, üst katımızda oturanlara eziyet vermemiş oluruz, dediler."

Yukarıdaki sünnette iki grup olduğu açıkça gösterilmiştir; gemilerin üst kısmında (tüm ayrıcalıklara ve avantajlara sahip olan) oturanlar ve geminin alt kısmında kalan (sınırlı veya hiç kaynağı olmayan) diğerleri. Bu nedenle ihtiyacı olanlara yardım etmek, yardım edebileceklerin sorumluluğundadır. Aksi takdirde, imtiyaz sahipleri daha az talihsiz olanın kötü durumunu görmezden gelirse herkes için kötü bir sonuç ortaya çıkacaktır.

\section{Tartışma ve Sonuç}

İslam, her Müslümanın bir dereceye kadar, özellikle zenginlik ve refah nimetine sahip olanların sosyal hizmetlerde bulunmasını emreder. İslam'ın üçüncü şartı olan zekât, Müslümanların Allah'ın emrine sadık kalmalarını ve daha az şanslı olan diğer Müslümanlara şefkat göstermelerini sağlar. Zekât, sadece zengin ve fakir arasındaki yakın ilişkiyi teşvik etmekle kalmaz, aynı zamanda İslam'da sosyal refah ve hizmetler sisteminin uygulanmasına da işaret eder.

Cami Hz.Muhammed (sav) zamanında sadece ibadethane olarak değil, aynı zamanda eğitim ve öğretim merkezi, sosyal aktivite merkezi, toplum geliştirme merkezi, bilgi merkezi, adli merkez, iletişim merkezi, toplu etkileşim merkezi, tedavi ve acil durum, rehabilitasyon merkezi ve sanat merkezi olarak da işlev görmekteydi. O zamandan beri camiler ve musalla hala Müslüman cemaati tarafından önemli bir yer olarak kabul edilmektedir İmamlar ve üstad, Diyanet Dairesi tarafından tanınmakta ve atanmaktadır. Din hakkında geniş bilgiye sahiptirler ve Müslüman toplumunda oldukça fazla saygı görmektedirler. Topluma hizmet sunarken, imamlar ve üstad toplum refahını gerektiği gibi sağlamakla sorumludur. Bu nedenle, şeriat tarafından ana hatlarıla belirtileni belirli değerlere ve uygulamalara bağlıdırlar.

Profesyonel sosyal hizmet bilgisi ve becerileri, seküler ve Batı dünya görüşüne göre geliştirilmektedir. Bununla birlikte, İslami sosyal adalet doğrudan Kuran'dan ve Hz.Muhammed (sav)'in geleneklerinden gelmektedir. Bu ikisinin benzerliği, bireylerin, ailelerin, grupların ve toplulukların optimal sosyal işleyişini kolaylaştırma hedefinde yatmaktadır. Çalışmada belirtilen vaka örnekleri, makro sosyal hizmet (yani Nusrah Vakfı ve Zekât Toplama Merkezi) ve mikro sosyal hizmet (yani üstad/imamın yardımcı rolleri) uygulamalarına benzer. Dahası, İslami öğretiler ve temel mesleki sosyal hizmet, insan onurunu korumak, sosyal adalet, muhtaçlara yardım etmek ve bütünlük dâhil olmak üzere benzer değerleri paylaşır (Barise, 2005). Bu nedenle Zekât müesseseleri, imamlar, üstadlar, Müslümanlar ve camiler tarafından yapılan bu faaliyetler toplumda adaleti ve sosyal refahı korumak için yapılmaktadır. Peygamberin örnekleri aracılı̆̆ıla İslam, nihayetinde tüm insanlara barış ve uyum getirecek iyi işleri talep etmektedir. Bu bağlamda, İslami öğretiler ve profesyonel sosyal hizmet hedefleri benzemektedir.

Bununla birlikte, ana akım sosyal hizmet ile İslami öğretiler arasındaki tek fark (Barise, 2005), İslam'da müşterilere yardım etmek için verilen tüm taahhüt ve çabalardan sonra, hem hizmet sağlayıcının hem de müşterinin Allah'ın iradesine boyun eğmesi gerektiğidir. 0 nihai yardım kaynağıdır ve bu yardım birçok şekilde gelebilir (diğer insanlardan veya koşullardan). Bu, imamların uyguladığı yardım süreçlerinde görülmektedir. Nihayetinde imam ve üstad, müşteriye her zaman kendisinin sadece yardımı gönderen olan Allah'ın bir aracısı olduğunu hatırlatacaktır. Bu arada sorun(lar)a kolaylık beklerken danışana sabır tavsiyesi vurgulanır. 


\section{KAYNAKÇA}

Al-Krenawi, A. \& Graham, J. (2000). Islamic theology and prayer. International Social Work, 43, 289-304.

Barise, A. (2004). Islamic perspectives in social work: Towards a practice model. Paper presented at the 32nd Biennial Conference of the International Association of Schools of Social Work, October 2-5, Adelaide: Australia.

Barise, A. (2005). Social work with Muslims: Insights from the teachings of Islam. Critical Social Work. 6(2):1-11.

Chee, H. L., \& Barraclough, S. (Eds.). (2007). Health care in Malaysia: the dynamics of provision, financing and access. Routledge. New York.

Chi, M. (2015). Poverty rate down to $0.6 \mathrm{pc}$, Parliament told. Retrieved from http://www. themalaymailonline.com/malaysia/article/poverty-rate-down-to0.6pc-parliamenttold.

Country Meters. (2015). Population of Malaysia 2014.Retrieved from http://countrymeters. info/en/Malaysia.

Department of Social Welfare, Malaysia (DSW). (2012). Enhancing social work professionalism in Malaysia: Through the establishment of competency standards and the enactment of a social workers act. Retrieved from http://www.jkm.gov.my.

Fattahipour, A., \& Hatta, Z.A. (1992). Opportunities and market demands for social workers in Malaysia: 1992-2002. Penang: Universiti Sains Malaysia.

Frost \& Sullivan (2013). Rising patient demands and life expectancy in Asia Pacific continues to drive healthcare sector. Retrieved from http://www.prnewswire.com/newsreleases/frost--sullivan-rising-patientdemands-and-life-expectancy-in-asia-pacificcontinues-to-drivehealthcaresector-190131481.html.

Johari, F., Ab Aziz, M.R., Ibrahim, M. F., \& Mohd Ali, A.F. (2013). The roles of Islamic social welfare assistant (Zakat) for the economic development of new convert. Middle-East Journal of Scientific Research. 18(3):330-339.ISSN 1990-9233.

Johari, M. (2015). Religion and social work: Mosque centered social work of Muhammad, the Prophet of Islam. Retrieved from http://www.monajo.de/wpcontent/uploads/2014/07/Religion-and-Social-Work_Mosquecentered-SocialWork-of-the-Prophet-Muhammad_Mohammed-Johari_15-June-2013.pdf.

Khan, M.Z. (2008). Contribution of Islam to social work. Retrieved from http://www.radianceweekly.com/119/2445/the-039hard039-facts-of039mulayam039politics/2008-07-13/service-to-society/story-detail/contributionof-islam-to-socialwork.html.

Malaysian Association of Social Workers. (2012). Definition of social work. Retrieved from http://www.masw.org.my.

Moore-Polanco, R. L., \& Raghavan, C. (2006). The association of social development age on juvenile fear of crime levels in New York City public schools. Retrieved January 22, 2009, from http://www.allacademic.com/meta/p127348_index.html.

Mullaly, B. (2002). Challenging oppression: A critical social work approach. Don Mills, ON: Oxford University Press. 
Ng, C., \& Ratnam, L. (2012). Gender and poverty in Malaysia: Towards gender sensitivity in Lasallian education. Retrieved from

http://webcache.googleusercontent.com/search?q =cache: bb0BPHVi_6AJ:www.lasalleparc.org/lws/wp-content /uploads/ 2012/05/ PARC_Gender-Poverty-andLasallianEducation-in-Malaysia_final-1.doc $+\& \mathrm{~cd}=1 \& \mathrm{hl}=\mathrm{en} \& \mathrm{ct}=\mathrm{clnk}$.

Norani, M.H. (2012). The social worker act: Developing practice competences and overcoming constraints - a view from JKM. Retrieved from http://www.jkm.gov.my.

Saad, Z. M., Hatta, Z. A., \& Mohamad, N. (2010). The impact spiritual intelligence on the health of the elderly in Malaysia. Asian Social Work and Policy Review. 4:84-97.

Trading Economics. (2015). Malaysia unemployment rate. Retrieved from http://www.trading economics.com/malaysia/unemployment-rate.

Trading Economics. (2015). Malaysia GDP per capita 1960 -2015. Retrieved from http://www. tradingeconomics.com/malaysia/gdp-per-capita.

Turner, D., Cheboud, Lopez, R., \& Barise, A. (2002). Challenges for human rights advocacy and conflict resolution: The case of racism and racial conflict. Paper presented at the Conference of International Schools of Social Work, July 15-18, Montpellier France.

Van Hook, M. V., Hugen, B., \& Aguira, M. (Eds.). (2001). Spirituality within religious traditions in social work practice. Calgary: Brooks/Cole.

World Bank. (2014). Country at a glance. Retrieved from http://www.worldbank.org/en/country/malaysia. 